\title{
»En mexicansk blondine der sparker røv«
}

\author{
- Imitation og innovation i markedsføring af illegale \\ rusmidler $^{1}$
}

Marie Højlund Bræmer Ph.d., Post.doc. Center for Rusmiddelforskning, Aarhus Universitet Thomas Friis Søgaard Ph.d., Lektor. Center for Rusmiddelforskning, Aarhus Universitet

\begin{abstract}
In recent decades, the selling and purchasing of illicit drugs has been increasingly mediated by use of communication technologies such as mobile phones and social media apps. While the risk of police intervention has traditionally restricted dealers' use of advertisements to attract customers, the increasing technologization of retail-level drug markets has opened up new avenues for dealers' use of proactive marketing. This article contributes to the understanding of current transformations of the retail-level drug market by providing insight into how drug dealers compete for and try to attract customers by use of strategic and targeted advertising. Based on an in-depth analysis of the textual and visual content of 99 illicit »drug commercials" circulated through SMS-based (Short Message Service) drug lines, we demonstrate how drug dealers draw on a number of psychological and cognitive techniques such as repetition, association, humour, hooks, slogans and storytelling, all of which are also found in legal marketing. We conclude by arguing that there is a need for more studies on how "drug commercials" affect drug users' purchasing practices, including their choice of dealer.
\end{abstract}

\section{Keywords}

Drug markets; Drug dealers; Marketing, SMS, Denmark

Narkotikamarkeder, Stofsælgere; Markedsføring, SMS, Danmark

\section{Introduktion}

»Hej venner! Som de fleste har fået af vide, ændre vi priserne på brunt. Fremover lyder priserne på brunt følgende $3 \mathrm{~g}$ for $200 \mathrm{kr} 5 \mathrm{~g}$ for $300 \mathrm{kr}$ og $10 \mathrm{~g}$ for $500 \mathrm{kr}$. I samme om gang, som vi ændret priserne har vi self opgraderet kvalitet af røgen så i self altid vil få det bedste ryger. Priserne på grønt er stadig den samme $1.25 \mathrm{~g}$ for $100 \mathrm{kr}$ og $5 \mathrm{~g}$ for 300 kr. Del gerne budskabet. Med venlig hilsen Cool Style« (SMS-reklame).

1. Title in English: A Mexican Blonde who Kicks Ass. Imitation and Innovation in Illegal Drugs Advertising 
I de senere år har kriminologisk forskning peget på en øget teknologisering af detailmarkedet for illegale rusmidler, hvor køb og salg i stigende grad foregår på online »kryptomarkeder« (Barratt \& Aldridge, 2016), sociale medier (Demant mfl., 2019) eller ved hjælp af mobiltelefoner (Søgaard mfl., 2019). Denne udvikling har gjort illegale rusmidler mere tilgængelige (Bakken, 2021), og medført nye måder, hvorpå disse kan markedsføres (Moyle mfl., 2019). I denne artikel fokuserer vi på den voksende brug af »narkoreklamer« i det teknologiserede illegale stofmarked. Vi belyser, hvordan stofsælgere i stigende grad gør brug af gængse reklametekniske greb i markedsføringen af deres illegale produkter. Artiklen giver derved et indblik i nogle af de centrale udviklingstendenser, der i disse år former og forandrer detailmarkedet for illegale rusmidler.

Ligesom andre forbrugsvarer i det moderne samfund distribueres illegale rusmidler også gennem forskellige markeder (Caulkins \& Reuter, 1998). Studiet af illegale narkotikamarkeders sammensætning og funktionsmåde har længe været et centralt tema for både økonomer og kriminologer (Moeller, 2018a). Disse studier har vist, at selvom narkotikamarkeder ligner legale markeder idet de ofte er konkurrencebaserede i udvekslingen af varer og services (Reuter \& Kleiman, 1986), så er der også væsentlige forskelle. På narkotikamarkedet opererer sælgerne uden for lovens rammer, men også uden lovens beskyttelse. Førstnævnte betyder, at konkurrencen på dette marked hæmmes af, at sælgerne konstant må gå på kompromis med deres distributionseffektivitet for at opretholde et vist sikkerhedsniveau (Moeller, 2018a). Behovet for at holde distributionen hemmelig betyder fx, at det er svært at få sikker viden om varernes kvalitet, og at det kan være vanskeligt for sælgerne at få overblik over konkurrenternes prisniveau (Reuter \& Caulkins, 2004). Fraværet af lovens beskyttelse betyder også, at transaktioner på det illegale marked ikke er reguleret af kontrakter og formaliserede aftaler. Ligeledes findes der ingen kontrol- eller klageinstans, som sikrer fair konkurrence og transaktioner. Dette betyder, at der konstant er en risiko for at blive snydt og bedraget som både sælgere og købere må forholde sig til (Jacques mfl., 2014; Moeller \& Sandberg, 2015).

På denne baggrund har meget kriminologisk forskning været optaget af at belyse hvordan illegale stofmarkeder, til trods for at været gennemsyret af usikkerhed mht. til kvalitet, pris, tillid og forudsigelighed, alligevel fungerer som markeder (Moeller, 2018a). Dette inkluderer studier af, hvordan stofsælgere forsøger at undgå snyd samt hvordan de opbygger tillid til samarbejdspartnere (Moeller \& Sandberg, 2015), hvordan de håndterer gældsinddrivelse (Moeller \& Sandberg, 2017), og hvorledes prissætning af illegale rusmidler (varerne) ikke blot er styret af udbud og efterspørgsel, men også formes af sociale relationer mellem de involverede parter (Moeller \& Sandberg, 2019). Desuden har studier påpeget, at en central forretningsmæssig udfordring for stofsælgere er, hvordan de kan tiltrække (nye) kunder. Da køb og salg af illegale stoffer er ulovligt, kan sælgerne ikke åbenlyst reklamere for deres produkter (Reuter \& Caulkins, 2004). På 
det illegale stofmarked, må sælgerne derimod konstant veje fordelen ved synlighed overfor potentielle kunder op imod risikoen for at blive arresteret af politiet (Moeller, 2018a). Nyere forskning har imidlertid peget på, at den øgede brug af kommunikationsteknologier, såsom mobiltelefoner og SMS'er (Søgaard mfl., 2019) og sociale medieplatforme (Moyle mfl., 2019; Demant mfl., 2019), har ført til nye og mere sikre måder at markedsføre illegale produkter på. For stofsælgere, der opererer i åbne udendørs gademarkeder, såsom en park eller et gadehjørne, kan brugen af åbenlys reklame være meget risikofyldt for stofsælgere, da dette gør dem let genkendelige for ordensmagten (Kleiman, 1991). I modsætning hertil har øget brug af kommunikationsteknologier ført til en udvikling, hvor stadig større dele af stofhandlen foregår i relativt lukkede netværk, hvor adgangen er begrænset til de indviede, og hvor købere og sælgere kan kommunikere og handle i det skjulte (Moyle mfl., 2019). I disse lukkede markedsnetværk, er sælgerne og køberne forbundet via SMS-kæder og/eller via online platforme, og studier har vist, at stofsælgere i vidt omfang benytter SMS-kæder (Søgaard mfl., 2019), krypterede apps (Moyle mfl., 2019), Facebook (Demant mfl., 2019) og platforme på internettets mørkenet (kryptomarkeder) (Bancroft \& Reid, 2016) til at sende uopfordrede reklamer og slagtilbud til kunderne i deres netværk. Opsummeret kan man sige, at den øgede teknologisering af det illegale stofmarked har resulteret i en markant intensivering af stofsælgeres brug af proaktiv markedsføring i forsøget på at rekruttere og fastholde kunder.

Mens eksisterende forskning har peget på et øget brug af uopfordrede salgsreklamer i det teknologiserede illegale stofmarked, så er dette den første videnskabelige artikel, der laver en tekstnær analyse af de reklametekniske virkemidler, som anvendes i proaktiv marketing af illegale rusmidler. At belyse brugen af »narkoreklamer« og de reklametekniske virkemidler er vigtig fordi det kan give en bedre forståelse af, hvordan markedsføring kommer til udtryk og bliver virkningsfuld $i$ et stadigt mere teknologiseret kriminelt stofmarked.

Artiklen er baseret på analyse af 99 SMS-baserede »narkoreklamer« for cannabis, kokain, ecstasy og MDMA, der blev indsamlet som del af et studie af danske stofbrugeres køb af stoffer fra budservice. I artiklen belyser vi, hvordan stofsælgere anvender psykologiske strategier kendt fra andre typer af marketing samt traditionelle reklamegreb som humor, »hooks", slogans og "storytelling « til at få kunder i butikken. Set i lyset af at detailmarkedet for illegale rusmidler er kendetegnet ved et fravær af formel regulering, samt ved en konstant risiko for snyd og vold, viser vi, hvordan stofsælgerne gør brug af venskabsmetaforik og symbolske grænsedragninger i deres reklametekster, i forsøget på at konstruere en identitet som troværdige/fredelige og på den måde tiltrække kunder. 


\section{Baggrund}

Stofsælgeres brug af SMS-baserede »narkoreklamer« er del af en mere generel samfundsudvikling. I de seneste årtier er der i de fleste vestlige lande sket en massiv ekspansion i private virksomheders brug af markedsføring via SMS. Dette er en konsekvens af, at mobiltelefonen i dag er blevet allemandseje (Aslam mfl., 2016). Den altoverskyggende fordel ved reklamer per SMS er, at de fleste mennesker altid har deres mobiltelefon på sig og derfor, i markedst føringsøjemed, altid er tilgængelige. Derudover er SMS'er en effektiv måde at få en person til at forholde sig til en reklames indhold. Alle SMS-modtagere udsættes nemlig for en form for 'pre-view' af en beskeds indhold, og åbningsraten for SMS'er er 98 \%. E-mails og nyhedsbreve har til sammenligt ning sjældent en åbningsrate på mere end 35 \% (Aslam mfl., 2016). Et andet karakteristika ved SMS-reklamer er, at de sjældent bruges til massereklame. Derimod målrettes de typisk forbrugere, der tidligere har vist interesse for lignende indhold, hvorfor modtagerne ofte føler, at reklamerne er relevante for dem (Aslam mfl., 2016). Andre fordele ved SMS-reklamer er deres lave omkostninger, samt at der går meget kort tid fra en sælger har sendt en SMS til den tikker ind på modtagerens telefon. SMS-reklamer er derfor en af de mest effektive former for »direkte markedsføring".

Danmark udmærker sig ved en stram lovgivning på reklameområdet. En virksomhed skal fx have potentielle modtageres samtykke for at sende elektronisk reklame. Samme regulering findes ikke på markedet for illegale rusmidler. I Danmark har der været eksempler på stofsælgere, der har rundsendt SMS-reklamer til store grupper af personer, der ikke på forhånd har vist interesse for køb af illegale rusmidler. Ligesom på det legale marked, er det mest almindelige dog, at SMS-baserede stofreklamer målrettes personer, der tidligere har købt stoffer af en stofsælger. For mange kunder involverer førstegangskøb af stoffer via et »hash-« eller »coke-nummer« (Søgaard 2020), at de påtvinges SMS-reklamer fra sælgeren i fremtiden. Tidligere studier har vist, at stofbrugere, som erhverver illegale rusmidler fra såkaldte »budservicesælgere« ofte er i besiddelse af 3-8 sælgernumre, og at de jævnligt modtager SMS-reklamer fra forskellige stofsælgere (Søgaard, 2019). Det er derfor interessant at undersøge, hvilke reklametekniske greb stofsælgere gør brug af i forsøget på at få kunderne til at vælge netop deres service.

\section{Metode og data}

Artiklen bygger på data fra et kvalitativt forskningsprojekt om stofbrugeres erhvervelse af illegale rusmidler fra budservicesælgere. Forskningsprojektet involverede interviews med 28 stofbrugere i alderen 17-37, som alle havde 
førstehåndserfaring med at købe illegale rusmidler fra såkaldte »narkobude«. Alle interviewene varede mellem én og tre timer og de viste, at deltagerne i langt overvejende grad anvendte almindelige telefonopkald/SMS'er i deres kommunikation med sælgerne, mens kun få brugte krypterede smartphone apps, typisk Wickr (Søgaard, 2019; Søgaard \& Bræmer, 2020).

Tidligt i interviewprocessen blev det klart, at mange af deltagerne jævnligt modtog SMS-reklamer fra sælgere. Da vi antog, at disse reklamer kunne bibringe vigtige indsigter om stofsælgeres salgspraksis, blev interviewdeltagerne spurgt, om de ville dele eksempler på SMS-reklamer med os. Næsten alle deltagere indvilligede i dette. I nogle tilfælde videresendte deltagerne eksempler på modtagne SMS-reklamer i dagene efter interviewet. Enkelte deltagere var dog så flinke, at de med mellemrum videresendte SMS-reklamer flere måneder og år efter interviewet. Nogle deltagere tog deres telefon frem under interviewet og læste modtagne SMS-reklamer højt. I udskriften af interviewet blev de oplæste SMS-reklamer efterfølgende identificeret og gemt. I perioden medio 2017 til primo 2020 indsamlede vi 99 SMS-reklamer.

Alle deltagere har videregivet et udsnit af de SMS-reklamer, de har modtaget. Det betyder, at reklamerne i denne artikel ikke er repræsentative for alle typer af SMS-reklamer, som stofsælgere sender ud. En gennemgang af data viser dog, at vi er lykkes med både at indsamle eksempler på reklamer, som er meget basale i deres indhold og opbygning, og reklamer som er mere spektakulære og farverige i deres sprogbrug og metaforik. Studiet er godkendt af datatilsynet, og i artiklen er alle personer anonymiserede. Med få undtagelser er alle stednavne og sælger-brandnavne også anonymiserede.

\section{Analysetilgang}

Metodeanalytisk har vi arbejdet med en naiv, intuitiv læsning af reklamerne efterfulgt af en mere traditionel reklameanalytisk tilgang. I første omgang har vi gennemlæst reklamerne og hæftet os ved det umiddelbare, følelsesmæssige afkast. Hvilken stemning kommer man i? Er reklamerne kilde til undren, bekymring eller latter? Er de lette at afkode? Appelleres der til ens samvittighed, lyst, moral eller lignende? Efterfølgende har vi anvendt klassiske analysemodeller af tekstreklamer og kortlagt; hvor meget fylder teksten? Hvis der bruges emojis, hvilke og hvor store/hvor mange? Bliver symboler og emojis brugt til at underbygge det, der står i teksten eller er der et (intenderet?) misforhold mellem billede og tekst? Hvilket sprog er der brugt i reklamen? Bruges der slang? Fremsætter reklamen tydeligt en subjektiv holdning? Eller benyttes der påståede facts og såkaldte »objektive« argumenter? Vi har identificeret typiske temaer, samt kodet reklamernes brug af psykologiske overtalelsesstrategier, humor, jargon, slogans og storytelling. 
Et af reklamepsykologiens hovedværker er Walter Dill Scotts bog The Psychology of Advertising fra 1908, der særligt tematiserer hukommelsens og underbevidsthedens betydning for reklamer (Feldwick, 2018). Scott er forgangsmand for de reklameteoretiske retninger, der gør op med ideen om forbrugeren som udelukkende rationel. Derfor fokuserer Scott på alt det, der påvirker os følelsesmæssigt i reklamer, som vi ikke nødvendigvis reflekterer over. Det vi med andre ord husker, uden at vide hvorfor (Schultz \& Schultz, 2004). Scott fremhæver særligt tre forhold, som har betydning for, om vi husker noget ( $f x$ i en reklame): Gentagelse (når noget repeteres), intensitet (når noget sanses intenst, fx foranlediget af store overskrifter, billeder og stærke farver), og association (når man forbinder ét element med ét andet). I det følgende viser vi, hvordan vores materiale rummer brugen af alle tre strategier. Inden da giver vi et kort overblik over nogle basale karakteristika ved de SMS-baserede stofreklamer.

\section{SMS-reklamer for illegale rusmidler: Basisindhold og variation}

SMS-reklamerne i vores materiale varierer i længde, opbygning og indhold. Som vist nedenfor er de korteste og mest simple blot på et par linje, som har til formål at minde køberne om, at hvis de får lyst til stoffer, så er sælgeren let tilgængelig.

$$
\begin{aligned}
& \text { Hey ven husk vi er på hele } \\
& \text { natten også hvis du skulle } \\
& \text { mangle hjælp (SMS-reklame). }
\end{aligned}
$$

De simple reklamer indeholder også typisk information om, at sælgeren bringer ud og sommetider et estimat for deres leveringstid.

Karakteristisk for beskederne er også priser og referencer til typen af stof, ofte i form af slang: »Emma« og »tøsen« er fx slang for ecstasy og til tider også for MDMA.

$$
\begin{aligned}
& \text { Så har jeg noget vildt emma } \\
& \text { på lager med en tilbud på } 2 \text { for } \\
& 500 \text { god weekend (SMS-reklame). }
\end{aligned}
$$

I de længere SMS-reklamer betoner sælgerne tit deres produkters høje kva® litet, og nævner ofte stoftyper, prislister, rabatter ved køb af større mængder og det geografiske område, hvor der leveres:

\footnotetext{
Hey venner. Så sluttede

sommerferien desværre,
} 


\author{
håber i fik nyt ferien. Vi kører \\ derfor med nogle rigtig fine \\ tilbudspriser, 1 for 4 og to for \\ 8 og 3 for 1000! Vi har fået \\ en ny kvalitet hjem, som er \\ en tand skrappere end den vi \\ tidligere havde. Rigtig lækker \\ en af slagsen, forresten. \\ Leveringtid i Telborg og omegn \\ 15-25 min. Fortsæt god lørdag. \\ Mvh Pedro (SMS-reklame).
}

I de mere udspecificerede reklamer kommer sælgerne til tider med slagtilbud, som løber i en bestemt tidsperiode, og de nævner deres åbningstid (ofte fra 12 middag til omkring midnat). Desuden er SMS'ernes afsendelse ofte timet ift. tidspunkter hvor efterspørgslen på illegale rusmidler er særlig stor (Moeller, 2018b); sidst på ugen, tæt på lønningsdag, op til højtider og ferier (som påske, pinse og jul), som optakt til festivaller, omkring særlige mærkedage.

I både de korte og længere SMS-reklamer nævner sælgerne ofte deres brandnavn, som Cool Style, Jimbo, KK, Jack, Mekaniker Tom eller det ovenstående »Pedro«. Da budservicemarkedet er karakteriseret ved intens konkurrence, er brug af brandnavne ganske givet en strategi, sælgerne anvender for at få kunderne til at huske netop deres service (Søgaard, 2020). Et andet træk er, at mange af SMS-reklamerne indeholder stave- og grammatiske fejl, hvilket vidner om, at det illegale stofmarked er et relativt uorganiseret marked, hvor driftighed ofte trumfer finesse og detaljeorientering. I det følgende dykker vi nærmere ned i stofsælgernes brug af psykologiske og retoriske reklamegreb (som $\mathrm{fx}$ association, gentagelse og intensitet).

\title{
6. Psykologiske og retoriske greb: Association
}

Association betegner i reklameverdenen forbindelsen mellem produktet og noget, der rækker ud over produktet (Schultz \& Schultz, 2004). Som når man fx forbinder øl med fodbold eller maskulinitet. Eller når man, som i den følgende reklame, kobler rusmidler til ferie. 


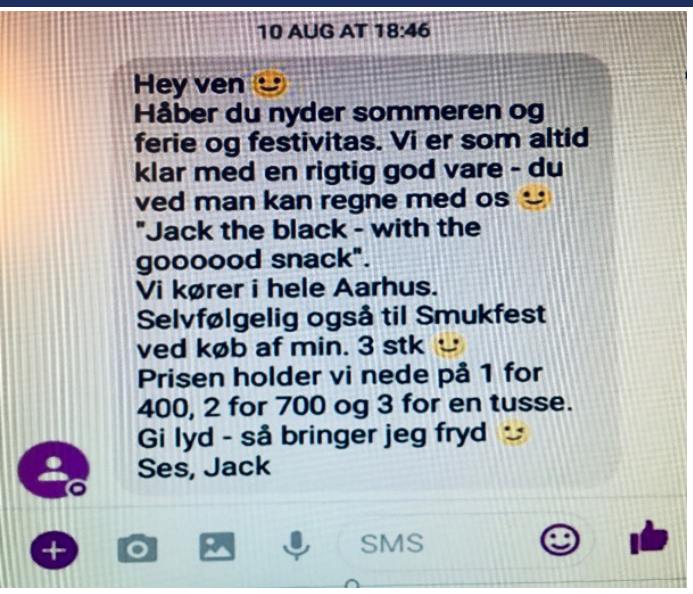

Ovenstående SMS-reklame fra stofsælgeren »Jack the Black« består af en begrænset ikonografi udgjort af tre smilende smileyer og én blinkende. Budskabet er basalt: Det er sommerferie og Jack the Black er leveringsdygtig i hele Aarhusområdet. Priserne er lave, og der gives mængderabat (»1 for 400, 2 for 700 og 3 for en tusse«). SMS'en sluttes af med en handlingsanvisning indpakket i sloganet »Gi lyd - så bringer jeg fryd».

Allerede i sin indledning appellerer reklamen til vores associative tankegang i sin sammenstilling af sommer, ferie, fest og rusmidler. Som modtager har man allerede efter de første to linjer mentalt placeret sig i sin dækstol med en longdrink. Og fordi »Jack the Black« tilbyder bududlevering, behøver man ikke vente længe på yderligere nydelse. Der er med andre ord dømt associativ afslapning, en stemning der forøges med referencen til Smukfest, også kendt som Skanderborg Festival. Reklamen benytter sig af endnu et klassisk reklamegreb, nemlig »normalisering/legitimering af forbrug", ved at appellere til en »særlig« tid. I reklamens tekstunivers kobles køb af rusmidler med et afbræk fra hverdagen, en legitim undtagelsestilstand på niveau med Gin og Tonics før middagen. Denne tankegang underbygges af metaforen »snack«, en betegnelse for noget, der ikke udgør et hovedmåltid, men spises mellem måltider for enten at stille en lille sult eller blot for nydelse. Reklamen opnår med sådanne associationsrækker, at modtageren forbinder produktet med noget positivt, og at man erindrer reklamen (og dermed afsenderen) bedre. Andre eksempler på association i vores data er forbindelsen mellem stofbrug og særlige anledninger. Fx kobles weekend ofte med stofbrug; afslapning med cannabisbrug; og fest med amfetamin, ecstasy/MDMA eller kokain.

\section{Gentagelser og slogans}

Et andet reklameteknisk greb er gentagelse. Gentagelse er når det samme ord eller symbol går igen, eller når man betjener sig af et slogan, en kort, fyndig formulering, der bruges til markedsføring ved systematisk repetition. Gentagelse er også et element i reklamen fra Jack, idet »Jack« benytter ikke mindre end to slogans, noget der går igen i alle hans reklame-SMS'er. "Gi lyd, så bringer jeg fryd« og »Jack the Black, with the goooooood snack». 
Udover at man husker Jack, er begge slogans ladede med positiv metaforik (»fryd《, "god«). Eksempler på andre slogans i vores materiale er »Du ringer jeg bringer« samt den kreative "Smid en besked, så kommer jeg forbi og tænder op i pejsen«. Ud over positiv sprogbrug og associationen mellem stofbrug og hygge, lægger begge slogans vægt på den lethed, hvormed stoffer kan erhverves. En potentiel køber skal bare ringe eller skrive en SMS, så tager sælgeren sig af resten. Et andet eksempel på gentagelse er de reklamer, der benytter det samme symbol og den samme tekst gentagne gange. Som i følgende, hvor tekst og ikonografi (med få ændringer) er den samme over tid.

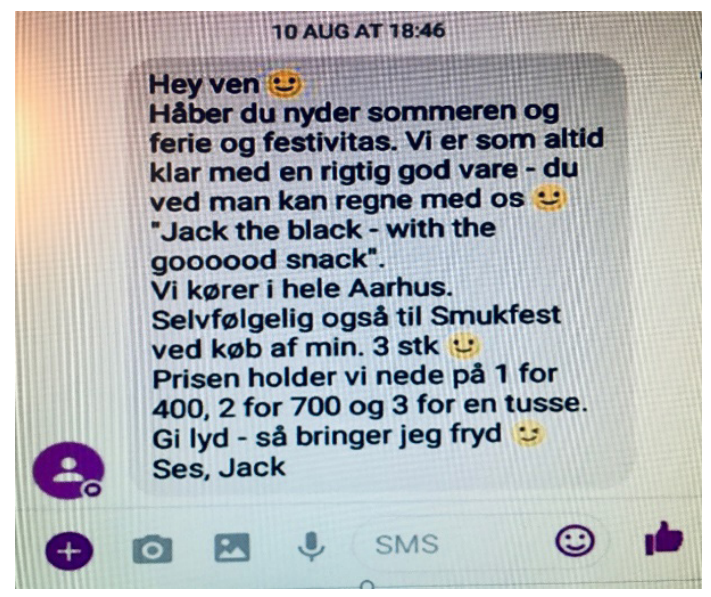

Budskabet i denne SMS-reklame er enkelt. Sælger har en god vare, og han bringer gerne ud. I alle tre beskeder er teksten ledsaget af en lille grøn figur, der både kan forestille en grøn drage (og hermed henvise til betegnelsen "grøn røg« for cannabis) eller en rummand (og hermed spille på metaforen »rumcigarer", slang for en joint). Selv om man kan diskutere hvorvidt den gentagne tekst er udtryk for et bevidst reklame-retorisk greb eller snarere et resultat af bekvemt og ressourcebesparende genbrug, har den repeterende opbygning den effekt, at man som kunde husker denne stofsælger i et hårdt konkurrerende marked.

\section{Intensitet}

Intensitet referer til at når noget sanses med stor styrke, huskes det bedre. I reklamer på det legale marked skabes intensive oplevelser hos modtageren ofte ved brug af store skilte, overskrifter eller symbolladede eller provokerende billeder, stærke farver m.m. Som tidligere nævnt kan fuld offentligt reklame for illegale produkter som cannabis og kokain være yderst risikabelt for sælgerne (Kleiman, 1991). En gennemgang af data viser imidlertid, at »intensitet« er et element, som også indgår i SMS-reklamer 
for illegale rusmidler. Gennem reklamernes indholdside skabes en intens oplevelse hos kunden, som appellerer mere til sanserne end fornuften, ofte gennem løfte om umiddelbar behovstilfredsstillelse. Dette gøres ved sætninger som »Du skriver bare, så kommer jeg forbi (h)vis det er« eller »Hey ven husk på vi er på hele natten også hvis du skulle mangle hjælp«, og derudover ved at slå på den korte (og faste!) leveringstid eller ved at sammenstille behov og levering af stoffer med umiddelbar nydelse og god stemning som i følgende:

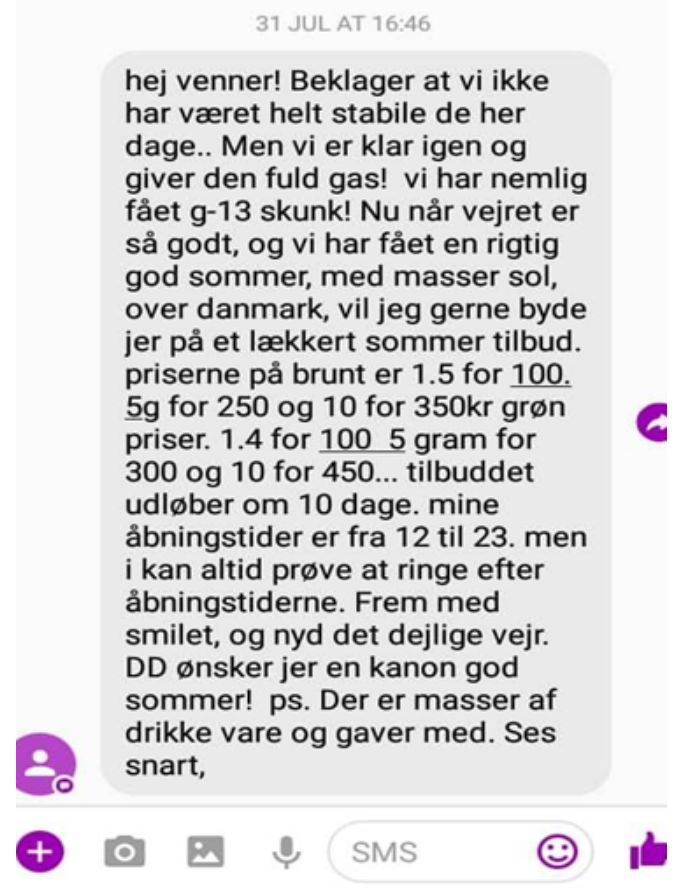

\section{Fælles fodslag}

En klassisk strategi i reklamer er at spille på et fællesskab mellem afsender og modtager, der cementerer, at sælger ved, hvad modtager har brug for, og derfor legitimt kan henvende sig (Stiegel, 2008). En sådan påstået forbindelse kan skabes på forskellig vis, fx ved hjælp af indforståethed.

I mange af de ovenstående reklamer tales der ikke direkte om stoffer. I stedet refereres der til produkterne ved hjælp af eufemismer som »den gode«, "snack" osv. I handel med illegale rusmidler indgår der altid overvejelser om sikkerhed, idet der konstant er en risiko for, at politiet gør brug af teleovervågning til at læse med i kriminelles SMS-korrespondance (Lentz, 2017). For stofsælgere kan der derfor være ræson i at bruge pæne omskrivninger, der 
i en potentiel retssag vil gøre det sværere for politiet at løfte bevisbyrden. Men det særlige indforståede sprog tjener også et andet formål, nemlig som en understregning af at »vi« (afsender og modtager) har noget til fælles. I vores data benyttes en mængde slang fra brugerkulturen til at understrege tilhørsforhold og fællesskab. Som fx i følgende SMS:

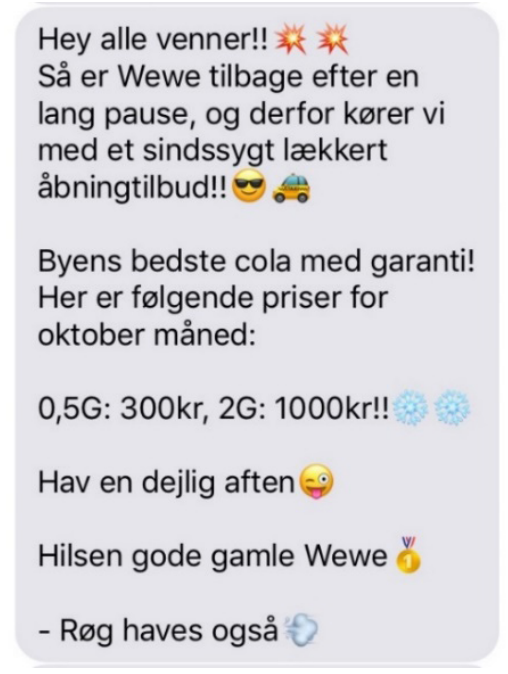

Udover sigende ikonografi, refereres der her til kokain med betegnelsen cola, mens røg dækker diverse afskygninger af cannabis. At det alt sammen forhandles af "gode gamle Wewe« er et retorisk kneb, som sælgeren anvender for at give potentielle kunder et indtryk af bekendtskab, tryghed og fælles historik. I vores materiale er »Emma« eller »Tøsen«, som før nævnt, faste vendinger for ecstasy og MDMA. »Cola«, »Julesne«, »flake« (og i det hele taget sne i alle afskygninger) og snefnug-emoji'er refererer til kokain. »Brunt« er hash, »grønt« er marihuana (pot), »lemon haze« er en bestemt cannabis sort, og røg-og kamel-emoji'er refererer generelt til cannabis. Udover at man som modtager føler sig på bøgelængde med afsenderen, så giver sprogbruget også modtagen en fornemmelsen af at tilhøre et fællesskab af indforståede.

\section{Krisestyring}

I den legitime reklamebranche referer »krisestyring « til en situation, hvor en producent/sælger indrømmer én eller anden grad af problemer, men betoner at disse bliver håndteret på kompetent vis (Liu mfl., 2017). Krisestyring er også et element i stofsælgernes SMS-reklamer, som i dette eksempel: »(..) beklager stilhed, byen er tørlagt, vi skriver når vi har varer igen«. I andre SMS'er signaleres der, at problemet ligger i fortiden, og at alt nu igen er under kontrol. Som i det følgende, hvor det betones, at der trods tidligere ustabilitet nu køres igen med »fuld gas«! 


\author{
hej venner! Beklager at vi ikke \\ har været helt stabile de her \\ dage... Men vi er klar igen og \\ giver den fuld gas! (...) Frem med \\ smilet, og nyd det dejlige vejr. \\ KK ønsker jer en kanon god \\ sommer! ps. Der er masser af \\ drikke vare og gaver med. Ses \\ snart. (SMS-reklame).
}

For stofsælgerne kan krisestyring også bestå i at forventningsafstemme at der i travle perioder kan forekomme forsinkelser på udbringning af stoffer. I nogle SMS'er opfordres køberne således til at bestille i god tid.

I reklameøjemed er »krisestyring « et greb, der bruges til at få sælgeren til fremstå pålidelig, oprigtig og som én, der vægter den ærlige kommunikation med sine kunder højt. Hvis man lykkes med denne strategi, er det lettere at signalere troværdighed fremadrettet (Liu mfl., 2017).

\title{
11. Venskabsmetaforik og tillid
}

Som tidligere nævnt er detailmarkedet for illegale rusmidler kendetegnet ved en høj grad af mistillid og jævnligt bedrag mellem sælgere og købere (Jacques mfl., 2014). Da tillid er en væsentlig faktor i stofkøberes valg af bestemte sælgere, har nyere studier vist, at stofsælgere på de sociale medier (Bakken, 2021) ofte designer deres online sælgerprofiler (billeder og tekst) med det strategiske sigte at højne potentielle køberes tillid til dem. I tråd med dette viste vores studie, at stofsælgere ofte performer en identitet som troværdige og ufarlige ved at trække på venskabsmetaforik. Nærmest samtlige af de indsamlede SMS-beskeder indledes med en venskabelig jargon eller en form for fingeret tætheds-indikator. Det kan være udtryk som »hej bro« eller »hej ven«, men kan også være mere kreative tituleringer af kunderne som »gutter og guttinder«, »hej venner og veninder" eller »Hva så folkens«. Brugen af venskabsmetaforik kan ses som sælgernes fors $\varnothing g$ på symbolsk at distancere sig fra gængse stereotyper om den voldelige og utilregnelige pusher (Coomber, 2006), og i stedet re-brande sig som ufarlige, venlige og imødekommende. Som når sælgerne, som i det følgende, afslutter SMS'en med; »med venlig hilsen (...)«.

\footnotetext{
Hey venner, jeg håber i haft en

god jul med glæde og gaver. I
} 


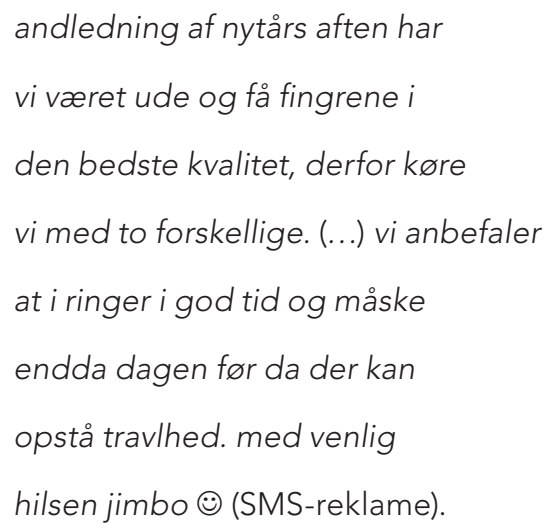

Tillidstemaet gør sig også gældende i formuleringer a la »l må gerne give nummeret videre til jeres venner e eller i vendingen "giv kun mit navn til venner«. Mens sådanne tilskyndelse tjener praktiske sikkerhedsformål, så som at reducere muligheden for, at et sælgernummer gives videre til en upålidelig person, der sladrer til politiet, så signalerer de også (indirekte) at sælgeren er ansvarlig og sikkerhedsbevidst, da han ikke sælger til hvem som helst, men kun til personer, som han selv eller andre kan sige god for.

\section{Humor}

I SMS-reklamerne kommer sælgernes forsøg på at konstruere en identitet som venlige og imødekommende også til udtryk i deres brug af humor. Dickinson og Wright (2017) har beskrevet hvordan humor, internt blandt stofsælgere, ofte bruges til lave symbolske grænsedragninger til andre, som anses som inkompetente og uprofessionelle. I tråd med dette kan brugen af humor i SMS-reklamer ses som en sælgers forsøg på symbolsk at distancere sig fra den primitive pusher-stereotyp, og i stedet konstruere en identitet som kløgtig, sjov og ufarlig.

Psykologiske eksperimenter har demonstreret, at brug af humor forhøjer positive holdninger til reklamer og produkter (Andersen, 2004). Dette gør sig også gældende i de interviews vi lavede med stofkøberne, hvor flere fremhævede, at det netop var de humoristiske SMS-reklamer, de synes bedst om og huskede. Udover at afsenderen af en reklame selvfølgelig er interesseret i at få etableret en positiv og gunstig stemning, kan et godt grin også få modtageren til at slappe af. Når vi slapper af, sænker vi paraderne og glemmer at være kritiske, hvorved vi lettere lader os overbevise om et produkts fortræffelighed (Stiegel, 2008). Følgende er et eksempel på brug af humor i SMS-reklamer for stoffer.

\footnotetext{
Hej alle sammen. Mekaniker

Tom har arbejdet på noget

disse dage, og kommet frem

til nogle helt nye friske
} 


\begin{abstract}
kvalitets vinterdæk med 0.6
mm for kun 400 kr. Så står

du og skal have skiftet dine

vinterdæk ud med nogle

kvalitets vinterdæk med 0.6

mm, så ring eller skriv endelig.

Service og tid noget vi

Prioriterer meget højt. Håber vi

ses ude på de glatte veje. Med

venlig hilsen jeres gode gamle

mekaniker tom. (SMS-reklame).
\end{abstract}

Afsenderen her illustrerer en høj grad af kreativitet med sin mekaniker-metafor, der er gennemført hele SMS'en igennem; fra de $0.6 \mathrm{~mm}$ dæek til de glatte veje. Sammenstillingen af illegale rusmidler med noget så hverdagsagtigt og lovlydigt som at få sat vinterdæk på sin bil, forekommer komisk, men virker også både ved at afstigmatisere og nedtone det kriminelle aspekt (og derved også risikoen fra politiet) ved at købe illegale rusmidler (se også Dickinson \& Wright, 2017). Endelig fungerer reklamen, idet den fanger læserens opmærksomhed qua sin appel til hovedbrud: Det er tilfredsstillende, at knække en kode, at bruge sin fantasi, så man pludseligt gennemskuer, at »vinterdæk« står for kokain, »mm« står for gram og at »mekanikeren«, der prioriterer service højt, er et billede på stofsælgeren, der ønsker at imødekomme og afhjælpe stofbrugernes behov.

\title{
12. Story Telling og den mexicanske blondine
}

Storytelling er en anden helt klassisk teknik, som virksomheder ofte bruger til at kommunikere et budskab. Budskaber pakket ind i en historie er lettere at huske end fakta og almindelige beskeder (Kang mfl., 2020). Også inden for SMS-reklamer for rusmidler, højner det tilsyneladende troværdigheden at vide noget om oprindelsen, som $f x$ »Direkte fra Brasilien« eller »hentet $\mathrm{i}$ Kbh.« Eller som i det følgende:

\footnotetext{
Hey venner, nu er vi trådt inde $i$

de kolde måneder og julen

nærmer sig. Derudover er det

ikke kun jule øllen der falder. Vi

her fået en mexicansk blondine
} 
der sparker røv. Vi køre

november måned med 3 stk til

1000 kr. Hilsen jimbo :) (SMS-reklame).

Brugen af story-telling, og direkte eller implicitte referencer til geografiske produktionsregioner, er udbredte måder hvorpå stofsælgere prøver at give indtryk af at deres produkter har en høj kvalitet. Andre studier har fx vist, at stofsælgere gør brug af udtryk som Hollandsk MDMA, Colombiansk kokain og Marokkansk Marihuana (Bancroft \& Reid, 2016).

\section{Konklusion}

I denne artikel har vi vist, hvordan de senere års øgede teknologisering og intensiverede konkurrence på det illegale stofmarked har afstedkommet en situation, hvor mange stofsælgere er blevet mere innovative i deres brug af proaktiv markedsføring til at rekruttere og fastholde kunder. Vi har anskueliggjort hvordan sælgerne, i deres fabrikation af SMS-reklamer i høj grad betjener sig af virkemidler og greb, som vi kender fra den legale reklameverden. I analysen tog vi udgangspunkt i Scotts klassiske hukommelses-psykologi - kondenseret i begreberne association, gentagelse og intensitet -, som vi brugte til at belyse, hvordan sælgerne benytter gængse reklamestrategier, så som storytelling og humor, i forsøg på at påvirke modtagerne. Vi demonstrerede også, hvordan SMS-reklamerne i deres opbygning både spiller på og appellerer til basale menneskelige behov som fællesskab, sikkerhed og lyst. Ved at signalere samhørighed, venskab og indforståethed i både krisetider og glædesstunder, spiller flere af reklamerne desuden på underbevidst og bevidst trang til at få dækket sådanne behov ved hjælp af rusmiddelskøb og -brug.

Selvom et af de mest slående fund i dette studie er, at de reklametekniske greb, der anvendes af kriminelle stofsælgere, i høj grad minder om dem, der også anvendes i reklamer på det legale marked, så er der også forskelle. En forskel er, at stofsælgernes SMS-reklamer ofte indeholder både stave- og grammatiske fejl, hvilket vidner om, at det illegale stofmarked er et relativt uorganiseret marked, hvor driftighed ofte »overruler r raffinement og detalje-orientering. En anden forskel er at transaktionerne mellem udbydere og aftagere på det illegale stofmarked ofte finder sted i en kontekst, hvor vold, snyd og bedrag altid lurer som en reel eller forestillet risiko. Derfor bliver det vigtigt for sælgerne at gøre brug af venskabsmetaforik for at kommunikere til potentielle kunder, at de er ufarlige og troværdige.

Brugen af proaktiv markedsføring og klassiske reklamegreb kan ses som et udtryk for at handlen med illegale rusmidler i de senere år er blevet mere professionaliseret og i nogle tilfælde er et direkte resultat af (organiserede) kriminelles 
bevidste business-strategier. Man kan dog diskutere om den brede udbredelse af sådanne kommunikative greb i højere grad er et udtryk for at flere kriminelle sælgere ubevidst imiterer kommunikationsformer og -greb, som cirkulerer i mainstream- og forbrugersamfundet. I Danmark, og andre vestlige lande, er kommercielle reklamer blevet faste elementer i hverdagslivet. Ikke blot gennemsyrer reklamer og målrettet kommunikation Tv-programmer, film, radioindslag, blade, det offentlige rum og sociale medieplatforme. Reklamefrase, -slogans og -jingler er også blevet integreret i hverdagssproget og det sociale liv (Mitchell mfl., 2007). På denne baggrund er det sandsynligt at de klassiske reklametekniske virkemidler, som optræder i narkotikareklamer, ikke altid er udtryk for bevidste business-strategier, men derimod er resultat af »entreprenel bricolage« (Baker \& Nelson, 2005), hvor sælgerne i en uorganiseret, og til tider uintenderet, proces trækker på forhåndenværende ressourcer, kommunikationsformer og -greb, som cirkulerer i mainstream samfundet, i deres markedsføring af illegale rusmidler. Forskning har vist at kriminelle ofte lærer af og imiterer hinanden (Akers \& Jennings, 2009). Brugen af succesfulde kriminalitetskoncepter, som eksempelvis illegale SMS-reklamer med en specifik opbygning, kan derfor formodes at spredes som ringe i vandet. Imitation skal her ikke forstås som én-til-én kopiering, men snarere som en sammenstyknings-proces, hvor individuelle sælgere på ad hoc vis genbruger, men også rekombinerer forhåndenværende og heterogene kommunikative ressourcer til nye formål, uden nødvendigvis at have en klar forudgående plan.

Spørgsmålet er slutteligt, hvilken betydning stofsælgeres skift til mere proaktive markedsføringsstrategier har for brugen af illegale rusmidler. Demant mfl. (2019) har peget på at et problem ved stofsælgeres brug af reklamer i lukkede Facebookgrupper er, at reklamer for cannabis ofte optræder side om side med tilbud på kokain, amfetamin, ecstasy og MDMA. Der er derfor en risiko for at nogle unge cannabisbrugere kan blive fristet til at prøve hårdere stoffer. Samme pointe kan man lave når det kommer til brugen af SMS-baserede stofreklamer, hvor såkaldte »bløde« og »hårde« stoffer også ofte markedsføres i de samme reklamer. Et andet potentielt problem ved markedsføring af stoffer via SMS'er er, at de fleste mennesker, som tidligere nævnt, altid har deres mobiltelefon på sig. Det at man konstant eller jævnligt modtager en stofreklame kan pirre nogle stofbrugeres lyst og stoftrang, hvilke kan få dem til at bruge stoffer i situationer, hvor de ellers ikke ville have gjort det (Søgaard, 2020). Der er således en risiko for at stofsælgeres brug af SMS-reklamer kan føre til øget stofbrug for nogle brugere. Slutteligt er der også en mulighed for at brugen af SMS-reklamer vil føre til en øget normalisering af både brugen og købet af illegale rusmidler. Da SMS-reklamerne ofte gør brug af humor, en venlig tone, venskabsmetaforer og farverige associationer flyttes stofkøbet så at sige fra en stigmatiseret sfære, associeret med kriminalitet, vold og utryghed, til en sfære, hvor det at købe illegale rusmidler trivialiseres og i nogle tilfælde sågar transformeres til en sjov og underholdende shopping-aktivitet. 


\section{Finansiering:}

Denne artikel er baseret på et forskningsprojekt, som er finansieret af Center for Rusmiddelforskning, Aarhus Universitet.

Kontaktoplysninger

Marie Højlund Bræmer:

mhb.crf@psy.au.dk

Thomas Friis Søgaard: tfs.crf@psy.au.dk

\section{Referencer:}

Akers, R.L. and Jennings, W.G. (2009). The Social Learning Theory of Crime and Deviance. I: Marvin D. Krohn, Alan J. Lizotte and Gina Penly Hall (Red.), Handbook on Crime and Deviance. Heidelberg, London, New York: Springer.

Andersen, L.P. (2004). The Rhetorical Strategies of Danish TV Advertising. A study of the first fifteen years with special emphasis on genre and irony (ph.d.-afhandling). Frederiksberg: School of Marketing, CBS/Samfundslitteratur.

Aslam, W., Batool, M. and UI Haq, Z. (2016). Attitudes and Behavior of the Mobile Phones Users towards SMS Advertising: A Study in an Emerging Economy. Journal of Management Sciences, 3(1), 63-80. DOI: 10.20547/jms.2014.1603105

Baker, T. and Nelson, R.E. (2005). Creating Something from Nothing. Resource Construction through Entrepreneurial Bricolage. Administrative Science Quarterly, 50, 329-366.

Bakken, S. A. (2021). Drug dealers gone digital: using signaling theory to analyse criminal online personas and trust. Global Crime, 22(1), 51-73, DOI: 10.1080/17440572.2020.1806826

Bancroft, A. and Reid, P.S. (2016). Concepts of illicit drug quality among darknet market users: Purity, embodied experience, craft and chemical knowledge. International Journal of Drug Policy, 35, 42-49. DOI: 10.1016/j.drugpo.2015.11.008

Barratt, M.J. and Aldridge, J. (2016). Everything you always wanted to know about drug cryptomarkets* (*but were afraid to ask). International Journal of Drug Policy, 35, 1-6. DOI: 10.1016/j.drugpo.2016.07.005

Caulkins, J. and Reuter, P. (1998). What price data tell us about drug markets. Journal of Drug Issues, 28(3), 593-612. DOI: 10.1177/002204269802800302

Coomber, R. (2006). Pusher myths: Re-situating the drug dealer. London: Free Association.

Demant, J., Bakken, S.A., Oksanen, A. and Gunnlaugsson, H. (2019). Drug dealing on Facebook, Snapchat and Instagram: A qualitative analysis of novel drug markets in the Nordic countries. Drug and Alcohol Review, 38(4), 377-385. DOI: 10.1111/dar.12932

Dickinson, T. and Wright, R. (2017). The funny side of drug dealing: Risk, humor, and narrative identity. Criminology, 55(39, 691-720. DOI: 10.1111/1745-9125.12148

Feldwick, P. (2018). How does Advertising work: https://www.adassoc.org.uk/wp-content/ uploads/2016/11/Advertisings-BigQuestions-How-does-advertising-work.pdf Besøgt 12.04.2020.

Jacques, S., Allen, A. and Wright, R. (2014). Drug dealers' rational choices on which customers to rip-off. International Journal of Drug Policy, 25, 251-256.

Kang, J.A., Hong, S. and Hubbard, G.T. (2020). The role of storytelling in advertising: Consumer emotion, narrative engagement level, and word-of-mouth intention, Journal of Consumer Behavior, 19(1), 46-57, Wiley Online Library. DOI.org/10.1002/cb.1793

Kleiman, M.A.R. (1991). Modelling drug markets. National Institute of Justice. Project No. 89-U-CX-0001: 248 sider.

Lentz, L.W. (2017). Retsplejelovens regulering af politiets adgang til teledata. Tidsskrift for Kriminalret, 10, 1240-1252. 
Liu, Y. Shankar, V. and Yun, W. (2017). Crisis Management Strategies and the Long-Term Effects of Product Recalls on Firm Value, Journal of Marketing, 81, 30-48. DOI: 10.1509/ jm.15.0535

Mitchell, V., Macklin, J.E. and Paxman, J. (2007). Social uses of advertising, International Journal of Advertising, 26(2), 199-222. DOI: 10.1080/10803548.2007.11073007

Moeller, K. and Sandberg, S. (2015). Credit and trust: Management of network ties in illicit drug distribution. Journal of Research in Crime and Delinquency, 52, 691-716.

Moeller, K. and Sandberg, S. (2017). Debts and threats: Managing inability to repay credits in illicit drug distribution. Justice Quarterly, 34, 272-296.

Moeller, K. (2018a). Drug Market Criminology: Combining Economic and Criminological Research on Illicit Drug Markets. International Criminal Justice Review, 28(3), 191-205.

Moeller, K. (2018b). Video-recorded Retail Cannabis. Trades in a Low-risk Marketplace: Trade Value and Temporal Patterns. Journal of Research in Crime and Delinquency, 55(1), 103-112.

Moeller, K. and Sandberg, S. (2019). Putting a price on drugs: An economic sociological study of price formation in illegal drug markets. Criminology, 57, 289-313. DOI: 10.1111/17459125.12202

Moyle, L., Childs, A., Coomber, R. and Barratt, M.J. (2019). \#Drugsforsale: An exploration of the use of social media and encrypted messaging apps to supply and access drugs. International Journal of Drug Policy, 63, 101-110. DOI: 10.1016/j.drugpo.2018.08.005

Reuter, P. and Kleiman, M.A.R. (1986). Risks and Prices: An Economic Analysis of Drug Enforcement. Crime and Justice: An Annual Review of Research, 7, 289-340. DOI: 0-22680801-7/8610007-0002\$01.00

Reuter, P. and Caulkins, J.P. (2004). Illegal 'lemons': price dispersion in cocaine and heroin markets. Bulletin on Narcotics. LVI (1-2), 141- 165.

Schultz, D.P and Schultz, S.E. (2004). A History of Modern Psychology (8th ed.). Belmont, CA: Wadsworth/Thompson Learning.

Søgaard, T.F., Kolind, T., Haller, M.B., and Hunt, G. (2019). Ring and bring drug services: Delivery dealing and the social life of a drug phone. International Journal of Drug Policy, 69, 8-15. DOI: 10.1016/j.drugpo.2019.02.003

Søgaard, T.F. (2019a). Buyer motives for sourcing illegal drugs from »drop-off« delivery dealers. I: J. Tieberghien \& Z. Kalo (red.): Explanations for drug use and drug dealing in social drug research, 123-136. Lengerich: Pabst Science Publishers.

Søgaard, T.F. (2020). BRUNE OG HVIDE BUDE. Mobiltelefonen som medskaber af budservicemarkedet for illegale rusmidler. Tidsskriftet Antropologi, 81, 85-105.

Søgaard, T.F. and Bræmer, M.H. (2020) »Bringer I ud?« Når unge køber illegale rusmidler fra bude. STOF tidsskriftet for viden om rusmidler og samfund, 36, 8-13.

Zhang, J. and Mao, E. (2008). Understanding the Acceptance of Mobile SMS Advertising among Young Chinese Consumers. Psychology \& Marketing, 25(8), 787-805. DOI: 10.1002/mar.20239 